\title{
The Effect of Brain-Based Teaching on Young EFL Learners' Self-Efficacy
}

\author{
Parastoo Alizadeh Oghyanous ${ }^{1}$ \\ ${ }^{1}$ English Department, Faculty of Foreign Languages, Central Tehran Branch, Islamic Azad University, Iran \\ Correspondence: Parastoo Alizadeh Oghyanous, English Department, Faculty of Foreign Languages, Central \\ Tehran Branch, Islamic Azad University, Iran. E-mail: alizadeeng2@gmail.com
}

Received: March 25, 2017 Accepted: April 25, 2017 Online Published: April 27, 2017

doi: 10.5539/elt.v10n5p158 URL: http://doi.org/10.5539/elt.v10n5p158

\begin{abstract}
The present study aimed to investigate the effect of brain-based teaching on the self-efficacy of young EFL learners. The initial participants of the study were 90 learners within the age range of 13-16 who were selected based on convenience sampling. Theses 90 young EFL learners were given a Flyers test the scores of which were used to choose 60 homogeneous learners whose scores fell within the range of $+/$ - one standard deviation from the mean. The 60 selected learners were then divided into an experimental and a control group. A Self-Efficacy Questionnaire for Children (SEQ-C), developed by Muris (2001) was administered to the participants in both groups before and after the treatment after being translated into Persian and piloted for reliability check. To implement brain-based teaching in the experimental group, the researcher taught the lessons based on the three techniques of Brain Based Teaching Approach (BBTA). The three techniques used were Relaxed Alertness (RA), Orchestrated Immersion (OI) and Active Processing (AP) in line with Thomas and Swamy (2014). The results of statistical analyses indicated that brain-based teaching approach had a significant effect on students' self-efficacy. The findings of the study can have implications for both students and EFL teachers in the realm of foreign language learning and teaching.
\end{abstract}

Keywords: brain-based teaching, young EFL learners, self-efficacy

\section{Introduction}

According to Howard-Jones (2008), by the development of neuroscientific knowledge, some experts and instructors are being gradually aware of the advantages of neuroscience regarding the brain and its function when students learn. The development of neuroscientific knowledge has increased brain-based teaching. In contrast to the prior beliefs that learning involves only the superior part of the human body, brain-based teaching approach sticks to the idea that learning consists of the total structure of a human being (R. N. Caine \& G. Caine, 1991, 2002; Jensen, 1998). If learning is "authentic", the students will learn better, because it deals with real world difficulties and presentations (R. N. Caine \& G. Caine, 1990, 2002; Sousa, 1995, 1998; Jensen, 1998). Since the brain progress and development is reliant on an individual's experiences, the challenge is for teachers to change their techniques of teaching and change the model from a "one fits all" to a "developed setting" for each student (R. N. Caine \& G. Caine, 1990, 2002; Jensen, 1998; Evan, 2007). The teacher is responsible for providing the suitable classroom setting, which focused on instructions that accommodate how the brain learns, that will improve brain functionality in processing and making data correctly, based on the level of individual learners. It is obvious that neuroscience is responsible for supplementary data related to human learning and the efficacy with which learning occurs because efficacy is related to the way learners think about themselves and their learning.

The notion of learners' self-beliefs is a subject, which was at the center of attention in education recently. About two decades of analysis has indicated that self-beliefs are influential issues on academic accomplishments, which is the reason of self-beliefs (Pajares, 2003). According to Bandura (1986), self-efficacy is the most powerful belief among all beliefs, which plays a key role in defining people's decision making, determining the efforts in the face of experiment, and the degree of anxiety or assurance they had in doing the task at hand.

Bandura defined self-efficacy as people's decision of their abilities to form and perform sequences of action required to achieve the selected kinds of performance. It is related to the skills one has with the evaluation of what one can do with any kind of those skills. Delcourt and Kinzie (1993) stated that perceived self-efficacy 
reflects an individual's assurance in his or her capability in performing the behavior essential to create particular results.

Although brain-based teaching and self-efficacy are two important concepts, a review of the current empirical research on self-efficasy (e.g., Basereh, \& Pishkar, 2016; Estonella Mastan, \& Maarof, 2014; Ghabdian, \& Ghafournia, 2016; Kırmızı, \& Dağdeviren Kırmızı, 2015; Mall-Amiri, \& Sadeghi, 2014; Yangon Ersanlo, 2015) and brain-based teaching (Demirhan, Önder, \& Beşoluk, 2014; Saleh, 2012; Siercks, 2012) indicates that, to date, no study has been carried out to explore the effect of brain-based teaching on self-efficacy which will be the focus of the present study.

\section{Literature Review}

\subsection{Self-efficacy}

According to Pajares and Valiante (1997), the beliefs that students have about their academic competences is helpful in determining what they do with the information and talents they have. Moreover, this is effective in clarifying why students' academic results may be different distinctly despite the fact they have the same level of capability. 'self-efficacy beliefs' is defined by Bandura and Schunk (1981) as people's assessment of their abilities in organizing and executing ways of achievement necessary to do selected kinds of presentation. Self-efficacy is primarily a cognitive self-concept of an individual regarding his perceived competences in a given task. It is worth noting that self-efficacy is task-specific which means individuals' previous involvements in the tasks help them recognize their level of self-efficacies. Researchers come to an agreement that individuals who notice themselves capable on a given task will perhaps involve more than the time they do not feel themselves capable enough (Pajares, 1996; Jackson, 2002; Ching, 2002; Margolis \& McCabe, 2003). Therefore, greater levels of self-efficacy will result in students' determination in tasks in order to overcome problems.

In their study, Amini and Sadeghi (2014) tried to examine the relationship among EFL learners' self-efficacy, extroversion and writing ability. To this end, 114 sophomore and junior learners, studying in English Translation and literature in Islamic Azad University at Central Tehran were randomly chosen. They were with the age range of 20-45. The participants were given two questionnaires such as General-Self Efficacy (GSE), and Eysenck Personality (EPQ). In addition, sections 2 and 3 of PET related to writing were administered. The relationship among the variables was analyzed through Spearman non-parametric formula. The findings of data analyses showed that there is no significant relationship among EFL learners' self-efficacy, extroversion and writing ability.

ErsanlÕ (2015) has conducted a quantitative study in order to explore the relationship between the academic self-efficacy levels and language learning motivations of 8 th graders. The 8th grade is important in Turkey, since at this time, the students have to take exams that determine the high school they are to register. Consequently, it is a year when academic apprehensions are high. To fulfill this objective, Morgan-Jinks Student Efficacy Scale and Language Learning Orientations Scale by Noels et al. were administered to 257 participants from some various secondary schools. The findings of the study indicated that there is a low-level negative correlation between English language learning motivation and self-efficacy beliefs of students in Grade 8. Moreover, it was also concluded that language-learning motivations of the students show a significant difference that favors girls. On the other hand, there was no significant difference in the students' academic self-efficacy beliefs regarding gender. The outcomes about language learning motivations of the students based on the education level of the parents had a significant difference in students whose parents are more sophisticated with those of less sophisticated. In contrast, the students whose parents are university graduates have the lowest means while those whose parents are primary school and secondary school graduates have higher degree of self-efficacy.

Kırmızı and Dağdeviren (2015) tried to investigate higher education L2 learners in a Turkish context regarding writing self-efficacy, writing anxiety, and the reasons of writing anxiety. Data were collected through the Second Language Writing Anxiety Inventory (SLWAI) developed by Cheng, (2004), Causes of Writing Anxiety Inventory (CWAI), and Writing Efficacy Scale (WES) developed by Yavuz-Erkan (2004). 172 English Language and Literature students enrolled in a Turkish state university were participated in this study. In order to analyze the data, Descriptive, variance and correlation analyses were done. The findings of the study showed that the learners had a moderate level of writing self-efficacy based on content, accurateness, and design and unity sub-components of writing self-efficacy and have a great level of efficacy in punctuation. With respect to writing anxiety, the participants had a moderate level of writing anxiety. The findings of the study also proposed that male students had higher levels of writing self-efficacy but they had low level of writing anxiety. The study also showed that time pressure and negative evaluation of the teacher are considered as the main causes of writing anxiety on the part of Turkish L2 learners. In conclusion, through correlation analysis, it was concluded that 
there is a high negative correlation between writing self-efficacy and writing anxiety.

There is a study by Basereh and Pishkar (2016) about the relationship between Self-Efficacy Belief and self-directed learning of Iranian EFL learners at the advanced level. Based on the performance of students in a TOEFL PBT, 80 EFL learners who were studying English at the advanced level in Language Institute in Bandar Abbas, Iran were selected. The General Self-Efficacy Scale (GSE) validated by Schwarzer and Jerusalem (1995) and a standard copy of Self-Directed Learning Readiness Scale (SDLRS) developed by Guglielmino (1977) were used in this study. The results of the current study indicated that there was a correlation between Self-Efficacy Belief and self-directed learning of Iranian EFL learners at the advanced level. English teachers and EFL learners in the EFL and ESL context could use the results of the study.

Ghabdian and Ghafournia (2016) in their study investigated whether language learners' self-efficacy beliefs affect Iranian EFL learners' reading comprehension ability. The participants of the study were 120 English Language learners from different language schools. The participants received an adopted self-efficacy questionnaire in order to analyze their beliefs. Moreover, the adopted reading part of Michigan Test, as a test of English language proficiency was given to the participants in order to assess their reading comprehension. Through Pearson product-moment formula, it was concluded that there was a significant relation between self-efficacy and reading comprehension, and there was a positive correlation between self-efficacy and reading comprehension. Consequently, it might be assumed that the greater self-efficacious the learners are, the better they are in reading comprehension. The findings of the study indicated that gender did not have a relation to the language learners' self-efficacy beliefs.

\subsection{Brain-based Teaching}

The Brain Based Teaching Approach is an approach employed based on the Brain Based Learning Principles established by Caine \& Caine $(1990,2002)$ through three instructional methods, which related to these principles. The Brain Based Learning Principles are as follows:

- The brain is a comparable computer.

- Learning involves the entire structure.

- The search for meaning is inherent.

- The search for meaning is based on modeling.

- Feelings are threatening to modeling.

- Wholes and parts are processed concurrently by brain.

- Learning involves not only the focused attention, but also peripheral insight.

- Learning always includes both conscious and unconscious procedures.

- There are two kinds of memory: a spatial memory system and a set of systems for rote learning.

- When facts and skills are rooted in natural, spatial memory, one can comprehend and recall best.

- Learning is improved through experiment and inhibited by threat.

- $\quad$ Each brain is distinctive (R. N. Caine \& G. Caine, 1990, 2002).

There are three instructional methods related to brain-based learning:

- Orchestrated Immersion - makes a learning setting that fully engages students in many learning skills;

- Relaxed Alertness - removes fear in the learners while preserving highly stimulating settings; and,

- Active Processing - lets the learner combine and assume material by actively practicing it. (R. N. Caine \& G.Caine, 1990, 2002)

Contrasting traditional methods of schooling, which is often said to hinder learning through ignoring the brain's normal learning developments, the Brain Based Teaching Approach is believed to increase learning because of its holistic approach towards the students. As stated by Jensen (1996), it is an approach which favors the brain's best natural operational values, with the aim of achieving full consideration, understanding, meaning and memory.

There is a study by Saleh (2012) who tried to examine the efficacy of Brain Based Teaching Approach in improving students' scientific understanding of Newtonian Physics in the framework of Form Four Physics teaching. The method was employed based on the Brain Based Learning Principles developed by Caine and Caine (2002). This brain-compatible strategy involves specific attention and consideration towards seven main 
stages; (1) Initiation, (2) Explaining the result and painting big picture of the lesson, (3) Making connection, (4) Doing the learning activity, (5) Demonstrating student understanding, (6) Review for student recall and retention and (7) Screening the new issue. The usefulness of the teaching approach in the targeted setting would then be evaluated in a quasi-experimental research approach containing 100 students from two Secondary Schools in the northern peninsular Malaysia. Based on the qualitative analysis of the collected data from the Questionnaire of Subjective Items of Newtonian Physics, it was concluded that the teaching approach was effective in improving students' scientific comprehension of Newtonian Physics. It was found that a bulk of students from the experimental group who were instructed through the Brain Based Teaching Approach had a better scientific understanding of Newtonian Physics in comparison with the group that received traditional teaching method.

Siercks (2013) examined the usefulness of the brain based teaching approach on biology learning, attitude, critical thinking personality and self-efficacy scores of science teacher trainees. Moreover, science teacher trainees' beliefs about brain based teaching were studied. In his research, a mixed method approach was used and it contained of two sections: section A and B. Part A contained 65 science teacher trainees and section B was comprised of nine science teacher trainees. The outcomes of study based on section A showed that there was no significant effect of the teaching method on learning, attitude, critical thinking disposition and self-efficacy scores. In contrast, the outcomes of section B revealed that brain based teaching slightly had a significant effect on cognitive, affective and metacognitive features. This is parallel to the outcomes of some other researches. The present study also showed that numerous issues might have an effect on learners' cognitive and affective factors in addition to the teaching method.

\section{Research Question}

The present study aimed at answering the following research question:

RQ: Does brain-based teaching have a significant effect on young EFL learners' self-efficacy?

\section{Method}

\subsection{Participants}

The participants of the study were a sample of Iranian EFL learners from a language institute from Tehran. The initial participants of the study were 90 learners within the age range of 13-16 who were selected based on convenience sampling. These 90 young EFL learners were given a Flyers test, the scores of which were used to choose 60 homogeneous learners whose scores fell within the range of $+/$ - one standard deviation from the mean. The 60 selected learners were then divided into an experimental group and a control group.

\subsection{Instruments}

\subsubsection{Flyers Test}

The present study made use of a language proficiency test and a self-efficacy questionnaire to collect data. In order to determine the language proficiency of the participants, the Flyer test was used. The test was developed by the language assessment department of Cambridge University containing three sections; Listening (25 questions), Reading and writing (50 questions), and Speaking (10 minutes). This test measures language proficiency of young English learners up to A2 level in accordance to CEFR level.

\subsubsection{Self-Efficacy Questionnaire for Children (SEQ-C)}

A Self-Efficacy Questionnaire for Children (SEQ-C), developed by Muris (2001) was administered to the participants in both groups before and after the treatment to collect data on participants' self-efficacy. SEQ-C addresses three areas of self-efficacy: social self-efficacy, academic self-efficacy, and emotional self-efficacy. Social self-efficacy refers to the ability of children dealing with social challenges, academic self-efficacy states that child see himself capable of learning academic stuff, and emotional self-efficacy means the ability of the child in regulating his emotion and excitement when is under pressure of his peers. Totally SEQ-C has 24 items among them items $1,4,7,10,13,16,19$, and 22 measure academic self-efficacy, items 2, 6, 8, 11, 14, 17, 20, and 23 social self-efficacy, and items $3,5,9,12,15,18,21$, and 24 emotional self-efficacy. Respondents need to decide how well they can do the things mentioned in the items by choosing from 1 (not all) to 5 (very well).

With regard to the validity of the (SEQ-C), Muris (2001) reported the results of factor analysis on 330 children which supported the three dimensions of SEQ-C in accordance with the original components of SEQ-C. Additionally he reported the reliability of SEQ-C in the same sample as 0.88 for the total self-efficacy, 0.85 for social self-efficacy, 0.88 for academic self-efficacy, and 0.86 for self-regulatory efficacy. As in current study, SEQ-C was translated into Persian and after piloting it and checking the reliability, it was administered to the participants. Internal consistency of SEQ-C was also calculated and found 0.78 which was acceptable index of 
reliability.

\subsubsection{Procedure}

The study followed an experimental design and after formulation of research question and library research the study was formally started with sampling and continued with pretesting, intervention and posttesting. The sample of the study was chosen based on availability of the participants from a population of young EFL learners in Tehran. After spotting 90 young EFL learners from a foreign language institute in Tehran, Flyers test was administered. Based on the results of Flyers test, 60 language learners whose scores were closer to mean score of the sample were chosen as the actual participants of the study. Thirty of these young language learners served as the experimental group and the rest as the control group. Both groups took the SEQ-C as pretest and then underwent experimentation. To implement brain-based teaching in the experimental group, the researcher taught the lessons based on the three techniques of Brain Based Teaching Approach (BBTA). The three techniques used were Relaxed Alertness (RA), Orchestrated Immersion (OI) and Active Processing (AP) in line with Thomas and Swamy (2014). In other words, students in experimental group received regular assessment through test at the end of each session, positive and encouraging feedbacks, and breathing exercises to lower stress. In addition, the main points of the lesson were reviewed at the end of each session and students took a quiz related to the content of the ongoing session. The content of the lessons was in accordance with regular syllabus given to teacher by institute to follow. However, minor changes like review of main points of the lessons and regular quizzes for each session were made to the syllabus. It should also be noted that regular syllabus imposed by the institute was Cambridge English: Young Learners by Cambridge University Press.

After the instruction period which took about 12 sessions was complete, participants again completed the SEQ-C as posttest so that any changes to the self-efficacy scores could be traced and analyzed. The statistical analysis to find the answer to the research question was performed through running independent samples t-tests between experimental and control groups on pretest and posttest.

\section{Results}

The current study aimed at exploring the effect of brain-based teaching on young EFL learners' self-efficacy. As it was stated, the study adopted a pretest posttest design and accordingly as the initial step of the research process, the self-efficacy of Iranian EFL learners were tested and compared between experimental and control groups before experimentation. The results of analysis indicated that the two groups had equal mean scores. Experimental group had a mean score of $58.16(\mathrm{SD}=4.41)$ and control group had a mean score of $58.86(5.96)$ which were normally distributed $\mathrm{D}(30)=0.14,0.15, \mathrm{P}>0.05$ (see Table 1). Independent samples t-test also indicated that mean scores of the two groups were not significantly different at pretest, $\mathrm{T}(58)=0.51, \mathrm{p}=0.60$ (see Table 2).

Table 1. Descriptive statistics of groups at pretest and posttest

\begin{tabular}{|c|c|c|c|c|c|c|c|c|}
\hline & \multirow[t]{2}{*}{ Groups } & \multirow[t]{2}{*}{$\mathrm{N}$} & \multirow[t]{2}{*}{ Mean } & \multirow{2}{*}{$\begin{array}{l}\text { Std. } \\
\text { Deviation }\end{array}$} & \multirow{2}{*}{$\begin{array}{l}\text { Std. } \\
\text { Mean }\end{array}$} & \multicolumn{3}{|c|}{ ErrorKolmogorov-Smirnov ${ }^{\mathrm{a}}$} \\
\hline & & & & & & Statistic & $\mathrm{df}$ & Sig. \\
\hline \multirow{2}{*}{ Pretest } & 1.00 & 30 & 58.1667 & 4.41067 & .80527 & .148 & 30 & .090 \\
\hline & $\overline{2.00}$ & 30 & 58.8667 & 5.96388 & 1.08885 & .156 & 30 & .060 \\
\hline \multirow{2}{*}{ Posttest } & 1.00 & 30 & 81.3667 & 3.82806 & .69890 & .132 & 30 & .194 \\
\hline & 2.00 & 30 & 74.7667 & 5.57509 & 1.01787 & .155 & 30 & .065 \\
\hline
\end{tabular}


Table 2. Results of independent samples test between the groups at pretest and posttest

\begin{tabular}{|c|c|c|c|c|c|c|c|c|c|}
\hline & & $\begin{array}{l}\text { Leven } \\
\text { Equali } \\
\text { Varian }\end{array}$ & Test & $\begin{array}{l}\text { fort-test } \mathrm{f} \\
\text { of }\end{array}$ & for Equal & lity of & Teans & & \\
\hline & & $\mathrm{F}$ & Sig. & $\mathrm{t}$ & $\mathrm{df}$ & $\begin{array}{l}\text { Sig. } \\
(2-\text { ta }\end{array}$ & $\begin{array}{l}\text { Mean } \\
\text { d)Difference }\end{array}$ & $\begin{array}{l}\text { Std. Error } \\
\text { Difference I } \\
\text { I }\end{array}$ & $\begin{array}{l}\text { r5\% Confidence } \\
\text { Interval of the } \\
\text { Difference }\end{array}$ \\
\hline & & & & & & & & & Lower Upper \\
\hline Pretest & $\begin{array}{l}\text { Equal variances } \\
\text { assumed }\end{array}$ & $\mathrm{s} 2.723$ & .104 & -.517 & 58 & .607 & -.70000 & 1.35428 & -3.410882 .01088 \\
\hline 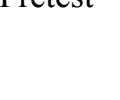 & $\begin{array}{l}\text { Equal variances } \\
\text { not assumed }\end{array}$ & & & -.517 & 53.418 & .607 & -.70000 & 1.35428 & -3.415842 .01584 \\
\hline Pos & $\begin{array}{l}\text { Equal variances } \\
\text { assumed }\end{array}$ & 84.029 & .049 & 5.345 & 58 & .000 & 6.60000 & 1.23471 & $4.12845 \quad 9.07155$ \\
\hline 1 Usticst & $\begin{array}{l}\text { Equal variances } \\
\text { not assumed }\end{array}$ & & & 5.345 & 51.372 & .000 & 6.60000 & 1.23471 & 4.121649 .07836 \\
\hline
\end{tabular}

In order to detect any changes in the self-efficacy of the EFL learners after Brain Based Teaching Approach, self-efficacy scores of the learners were compared and contrasted again in self-efficacy posttest. As seen in Table 1 experimental group had a mean score of $81.36(\mathrm{SD}=3.82)$ and control group had a mean score of 74.76 $(\mathrm{SD}=5.57)$ in posttest which were normally distributed $\mathrm{D}(30)=0.13,0.15, \mathrm{P}>0.05$. A cursory look indicates that both groups scored higher scores in self-efficacy posttest but experimental group scored relatively higher than control group. In addition, the scores were less variant in posttest for the experimental group. All these are evidence for better effect of Brain Based Teaching Approach on self-efficacy which was also confirmed by the result of independent samples t-test on the self-efficacy posttest scores. According to the results of independent samples t-test significant differences existed between experimental and control groups in self-efficacy posttest, $\mathrm{T}$ $(51.37)=5.34, \mathrm{p}=0.00$ (see Table 2$)$.

\section{Discussion and Conclusion}

The research question of the study was about the effect of brain-based teaching on young EFL learners' self-efficacy in Iran. Results of statistical analysis on self-efficacy scores obtained after administering SEQ-C showed that experimental and control groups were equal before being treated with brain-based teaching, but after the brain-based teaching it was found that experimental group had far better self-efficacy scores than control group. The results implied the positive effect of brain-based teaching on young EFL learners' self-efficacy in Iran. At theoretical level the findings are quite justifiable. Bandura (1997) and Zimmerman (1989, 1990) define self-efficacy as "the person's level of confidence that he/she can successfully complete a task or a series of tasks" (p.70) and Bandura (1997) delineates the main influences on self-efficacy as mastery experience, vicarious experiences or modeling, verbal or social persuasion, and physiological and emotional states. As seen in literature, any acts that can develop a positive feeling and a sense of achievement would be a help for self-efficacy promotion. The brain-based teaching approach implemented in the current study also had various components contributing to positive feeling and less emotional disturbance. Regular and gradual assessment can induce the feeling that achievement is obtainable, positive and encouraging feedbacks are encouraging and motivating and breathing exercises can lead to better emotional stability and less stress. In addition, the review of learning goals makes the achievement more objective and real to free the learners from academic confusion and insecurity. The focus of SEQ-C used in the current study was also on social, academic, and emotional self-efficacy that amazingly match the components of brain-based teaching employed in the experiment.

At practical level, the findings strongly suggest the use of brain-based teaching due to many benefits self-efficacy promotion have to the learners. Pajares (1996) argues that self-efficacy affects motivational and self-regulatory processes by making people make productive choices, exert efficient effort, be resilient, and experience less stress and anxiety. There are also many empirical studies affirming the relationship between self-efficacy and language achievement (e.g. Hsieh, 2008; Mills, Pajares, \& Herron, 2007, 2006; Tilfarlioğlu \& Cinkara, 2011). For instance the study by Pei-Hsuan et al (2008) on 500 undergraduates learning Spanish, German, and French showed that self-efficacy had positive correlation with ability and effort. Mills, et al., (2007) 
explored the relationship between self-efficacy, anxiety, and gender on the listening and reading proficiency of 95 French language learners in the United States. They reported a significant relationship between reading self-efficacy and reading proficiency in male and female students, and a significant a relationship between listening self-efficacy and listening proficiency in female students. They further reported that self-regulation component of self-efficacy was a strong predictor of the achievement.

With regard to brain-based teaching various strategies have been proposed for teaching young adolescents. Schiller and Willis (2008) presented a comprehensive overview of the potential strategies in accordance with standards rooted in brain research. Their strategies revolved around 6 macro strategies including providing safe environment, attending to learners' emotions, involvement of as many senses as possible, attending to learners' difference in age, development, learning styles etc., planning for special needs like visual or auditory impairments, and making learning meaningful by bridging between new material and prior knowledge. All these strategies have the potentials to be positively used in foreign language classrooms as they are based on universal learning principles extracted from brain research. Similar strategies were used in the current study and more research is needed to investigate other brain-based teaching strategies on social, academic, and emotional self-efficacy of Iranian young language learners. In addition, it is suggested that the impact of brain-based teaching on other aspects of self, like motivation, self-esteem, and learners' beliefs can be further investigated particularly in Iranian context of language education.

\section{References}

Bandura, A. (1986). Social foundations of thought and action: A social cognitive theory. New Jersey: Prentice-Hall, Inc

Bandura, A. (1997). Self-efficacy: The exercise of control. New York, NY: W. H. Freeman.

Bandura, A., \& Schunk, D. H. (1981). Cultivating competence, self-efficacy, and intrinsic interestthrough proximal self-motivation. The Journal of Personality and Social Psychology, 41(4), 586-598. https://doi.org/10.1037/0022-3514.41.3.586

Basereh, N., \& Pishkar, K. (2016). Self-Directed Learning and Self-Efficacy Belief among Iranian EFL Learners at the advanced Level of Language Proficiency. Journal of Applied Linguistics and Language Research, 3(1), $232-240$.

Ching, L.C. (2002). Strategy and self-regulation instructions contributors to improving students' cognitive model in an ESL programme. English for Specific Purposes, 13(3), 261-289. https://doi.org/10.1016/S0889-4906(01)00008-4

Demirhan, E., Önder, I., \& Beşoluk, S. (2014). Brain Based Biology Teaching: Effects on Cognitive and Affective Features and Opinions of Science Teacher Trainees. Journal of Turkish Science Education, 11(3), 65-78.

Caine, R. N., \& Caine, G. (1990). Understanding a brain-based approach to learning and teaching. Educational Leadership, 48(2), 66-70.

Caine, R. N., \& Caine, G. (2002). Beyin temelli ögrenme [Brain based learning]. (Interpreter Edt.: Gulten Ulgen). Ankara: Nobel Publications.

Delcourt, M. A, \& Kinzie, M. B. (1993). Computer technologies in teacher education: The measurement of attitudes and self-efficacy. Journal of Research and Development in Education, 27(1), 35-41.

Estonella Mastan, M., \& Maarof, N. (2014). ESL learners' self-efficacy beliefs and strategy use in expository writing. Procedia - Social and Behavioral Sciences, 116(25), 2360-2363. https://doi.org/10.1016/j.sbspro.2014.01.573

Evans, G. (2007). Counselling Skills for Dummies. John Wiley and Sons, London.

Ghabdian, F., \& Ghafournia, N. (2016). The Relationship between Iranian EFL Learners' Self- efficacy Beliefs and Reading Comprehension Ability. English Linguistics Research, 5(1), 38-50. https://doi.org/10.5430/elr.v5n1p38

Guglielmino, L. M. (1977). Development of the Self-Directed Learning Readiness Scale. Unpublished doctoral dissertation, University of Georgia. Dissertation Abstracts International, 38(11), 64-67.

Howard-Jones, P. (2008). Philosophical challenges for researchers at the interface between neuroscience and

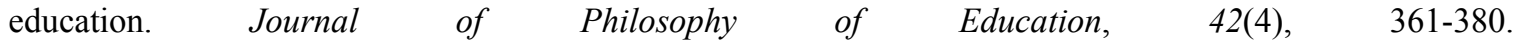
https://doi.org/10.1111/j.1467-9752.2008.00649.x

Hsieh, P. H. P. (2008). Why are college foreign language students' self-efficacy, attitude, and motivation so 
different? International Education, 38(1), 76-94.

Jackson, J.W. (2002). Enhancing self-efficacy and learning performance. The Journal of Experimental Education, 70(2), 243-55. https://doi.org/10.1080/00220970209599508

Jensen, E. (1998). Introduction to brain compatible learning. CA: The Brain Store Inc.

Kırmızı, O., \& Dağdeviren Kırmızı, G. (2015). An Investigation of L2 Learners' Writing Self-Efficacy, Writing Anxiety and Its Causes at Higher Education in Turkey. International of Higher Education, 4(2), 57-66. https://doi.org/10.5430/ijhe.v4n2p57

Mall-Amiri, B., \& Sadeghi, F. (2014). The Relationship among EFL Learners' Self efficacy, Extroversion and Writing Ability. Unpublished MA thesis, Islamic Azad University, Shahrood, Iran.

Margolis, H., \& McCabe, P. (2003). Self-efficacy: A key to improving the motivation of struggling learners. Preventing School Failure: Alternative Education for Children and Youth, 47(4), 162-169. https://doi.org/10.1080/10459880309603362

Mills, N., Pajares, F., \& Herron, C. (2006). A Reevaluation of the Role of Anxiety: Self-Efficacy, Anxiety, and their Relation to Reading and Listening Proficiency. Foreign Language Annals, 39(2), 276-294. https://doi.org/10.1111/j.1944-9720.2006.tb02266.x

Mills, N., Pajares, F., \& Herron, C. (2007). Self-efficacy of College Intermediate French Students: Relation to $\begin{array}{llll}\text { Achievement and Language Learning, 57(3), 417-442. } & \text { Motivation. }\end{array}$ https://doi.org/10.1111/j.1467-9922.2007.00421.x

Muris, P. (2001). Self-Efficacy Questionnaire for Children (SEQ-C). Key references: A brief questionnaire for measuring self-efficacy in youths. Journal of Psychology and Behavioral Assessment, 23(2), 145-149. https://doi.org/10.1023/A:1010961119608

Pajares, F. (1996). Self-efficacy beliefs in academic settings. Review of Educational Research, 66(5), 543-578. https://doi.org/10.3102/00346543066004543

Pajares, F. (2000). Self-efficacy beliefs and current directions in self-efficacy research. Retrieved June, from, 2016, http://www.emory.edu/EDUCATION/mfp/effpage.html

Pajares, F., \& Valiante, G. (1997). Influence of writing self-efficacy beliefs on the writing performance of upper elementary students. Journal of Educational Research, 90(4), 353-360. https://doi.org/10.1080/00220671.1997.10544593

Pei-Hsuan, P. H., \&, Schallert, D. L. (2013). Implications from self-efficacy and attribution theories for an understanding of undergraduates' motivation in a foreign language course. Contemporary Educational sychology, 33(6), 513-532.

Saleh, S. (2012). The effectiveness of the brain based teaching approach in enhancing scientific understanding of Newtonian physics among form four students. International Journal of Environmental \& Science Education, 7(1), 107-122.

Schiller, P., \& Willis, C. (2008). Inclusive literacy lessons for early childhood. Beltsville, MD: Gryphon House.

Siercks, A. (2012). Understanding and achieving brain-based instruction in the elementary classroom a qualitative study of strategies used by teachers. Unpublished MA thesis, University of Central Florida, Orlando, Florida.

Sousa, D. A. (1995). How the Brain Learns. Reston, VA: National Association of Secondary School Principals.

Sousa, D. (1998) Brain research can help principals' reform secondary schools. NASSP Bulletin, 82(598), 21-28. https://doi.org/10.1177/019263659808259804

Thomas, B. M., \& Swamy, S. S. (2014). Brain Based Teaching Approach - A New Paradigm of Teaching. International Journal of Education and Psychological Research (IJEPR), 3(2), 62-65.

Tilfarlioğlu, F. T., \& Ciftci, F. S. (2011). Supporting Self-efficacy and Learner Autonomy in Relation to Academic Success in EFL Classrooms (A Case Study). Theory and Practice in Language Studies, 1(10), 1284-1294. https://doi.org/10.4304/tpls.1.10.1284-1294

YangÕn ErsanlÕ, C. (2015). The relationship between students' academic self-efficacy and language learning motivation: A study of 8th graders. Procedia - Social and Behavioral Sciences, 199(5), 472- 478. https://doi.org/10.1016/j.sbspro.2015.07.534 
Yavuz-Erkan, D. (2004). Efficacy of cross-cultural e-mail exchange for enhancing EFL writing: A perspective for tertiary-level Turkish EFL learners. Unpublished Dissertation. Çukurova University, The Institute of Social Sciences English Language Teaching. Adana/Turkey.

Zimmerman, B. J. (1990). Self-regulated learning and academic achievement: An overview. Educational psychologist. 25(1), 3-17. https://doi.org/10.1207/s15326985ep2501_2

Zimmerman, B. J. (1998). Academic studding and the development of personal skill: A self- regulatory perspective. Educational psychologist, 33(2-3), 73-86. https://doi.org/10.1207/s15326985ep3302\&3_3

\section{Copyrights}

Copyright for this article is retained by the author(s), with first publication rights granted to the journal.

This is an open-access article distributed under the terms and conditions of the Creative Commons Attribution license (http://creativecommons.org/licenses/by/4.0/). 